\author{
(online) $=$ ISSN $2285-3642$ \\ ISSN-L = $2285-3642$ \\ Journal of Economic Development, Environment and People \\ Volume 5, Issue 2, 2016 \\ URL: $\underline{\text { http://jedep.spiruharet.ro }}$ \\ e-mail: office jedep@spiruharet.ro
}

\title{
Innovative Solutions for Companies to Reduce Gender Gaps (UK Study Case)
}

\author{
Andrei Angheluta ${ }^{1}$, Larisa Mihoreanu ${ }^{2}$, Carmen Costea ${ }^{3}$ \\ ${ }^{1}$ Alternative Sciences Association \\ ${ }^{2}$ Spiru Haret University Bucharest \\ ${ }^{3}$ The Bucharest University of Economic Studies, Romania
}

\begin{abstract}
For many years the gender gap has been a complex reality having economic implications and social decisiveness. No matter the percentage recently decreased, we still confront with social discriminations. In this paper we focused on the UK labour market so we developed a case study for a logistics company, using classification of the employees in different pay bands. Based on this study we created a state of the art human resource tool that can be applied worldwide and that help firms to analyse the root causes and to reduce the gender gap.
\end{abstract}

Keywords: gender gap, innovation, human resource toll.

Jel Codes: I 100, 01

\section{Introduction}

The gender pay gap has fallen by the largest amount since 1997, to just 10.2 per cent in April 2010, according to the UK Government's preferred measure. These days, the salary gap reaches $24 \%$, showing that during the work life, females get 300,000 GDP than the males.

In this study we look at the picture behind the headline statistics, and explain what the root causes of the gender gap are and what solutions can be applied when it comes to payment discrimination.

\footnotetext{
${ }^{1}$ Email address: anghelutaand@gmail.com

${ }^{2}$ Email address: cecostea@yahoo.com

${ }^{3}$ Email address: Imihoreanu@yahoo.com
} 


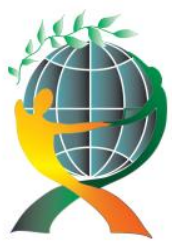

\author{
(online) $=$ ISSN $2285-3642$ \\ ISSN-L = 2285 - 3642 \\ Journal of Economic Development, Environment and People \\ Volume 5, Issue 2, 2016 \\ URL: $\underline{\text { http://jedep.spiruharet.ro }}$ \\ e-mail: office jedep@spiruharet.ro
}

The figure on which the Government prefers to base its analysis of the gender pay gap shows that in April 2010, the gap fell to 10.2 per cent, down from 12.2 per cent a year earlier. This is based on the median hourly earnings of full-time employees, as recorded by the Annual Survey of Hours and Earnings (ASHE) in April 2010.

The Government's preferred measure provides the lowest figure for the gender pay gap, but included in the ASHE release are a number of measures of the difference between the earnings of men and women. These range from 10.2 per cent to 19.8 per cent depending on the measure used (the latter figure is the difference in male and female median earnings, including both part-time and full-time workers). Analysis of this range of figures suggests that median full-time earnings may not be the most useful measure of the extent to which, across the whole economy, women's earnings are lower than men's. [IDS Pay Report 2011]

\title{
2. Which Statistical Methodology Should be Used - Median or Mean?
}

The first choice to be made when deciding on the appropriate measure of the gender pay gap is that between two different measures of averages: the median and the mean, since ASHE includes both median and mean earnings figures. Both measures have their merits, and both are useful in different situations, depending on what is being measured [Delistavrou, Tilikidou, 2014].

Where averages are to be used for comparative purposes it is not desirable for the results to be affected by unusually high or low results. The median is therefore the most appropriate measure in cases such as these, since it is simply the middle value, and takes little account of the extent of differences between figures in the sample. However, when calculating the gender pay gap, it is precisely these variations that we intend to measure.

The mean is therefore a more appropriate measure, in that it takes greater account of these differences. If a small number of high earners distort mean earnings upwards, but these highest earners are predominantly male, then that is part of the picture we are trying to capture. Regardless of the measure used, the gender pay gap has narrowed in 2010, and this is linked to the differential and time-lagged impact of the recession on the private and public sectors respectively.

\section{The Gender Pay Gap in 2010}

The extent of the gender pay gap varies depending on the type of employment considered. Among full-time employees, mean male hourly earnings were $f 16.25$ in April 2010, while the figure for women was f13.73. This represents a gap of 15.5 per cent, down from 16.4 per cent in 2009 . Until recently, the Office for National Statistics (ONS)produced only a figure for the gender pay gap based on full-time earnings, so in order to examine change in the gender pay gap over time, the figure below would be the most appropriate to use. The graph shows that since 1997, progress in closing the gender pay gap has been slow, and though the gap has narrowed slightly over this period, this has only been by about 5 per cent on the mean earnings measure. 


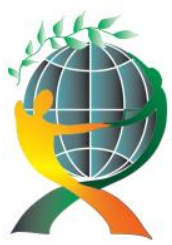

\author{
(online) $=$ ISSN $2285-3642$ \\ ISSN-L = $2285-3642$ \\ Journal of Economic Development, Environment and People \\ Volume 5, Issue 2, 2016
}

URL: $\underline{\text { http://jedep.spiruharet.ro }}$

e-mail: office jedep@spiruharet.ro

Charter 1. Gender Pay Gap 1997-2010, full-time hourly earnings excluding overtime

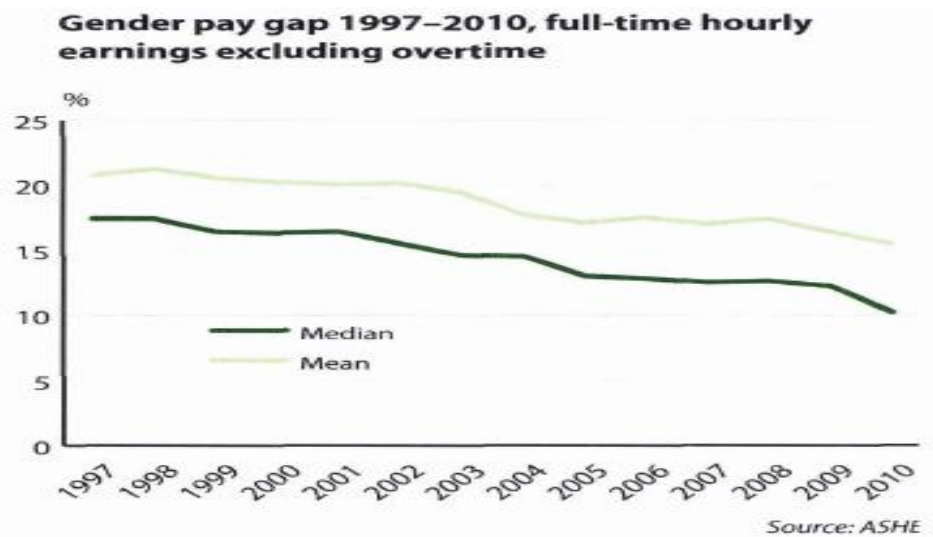

Among part-time workers, the mean gender pay gap is slightly lower than it is for full-time employees, standing at 11.7 per cent in April 2010, down from 11.8 per cent a year earlier. Men's hourly earnings were £12.06, compared to $\mathrm{f} 10.64$ for female part time workers. That the difference between male and female earnings for part-time workers is lower than that for full-time workers is in part explained by the fact that a significant number of women work part time in relatively well-paid jobs, as they often return to work on a part-time basis following the birth of a child. A further factor is that at the bottom end of the part-time earnings distribution, many of the lower-paid part-time jobs are filled by young people, among whom the gender pay gap tends to be narrower or even negative (i.e. in favour of women) [Blumberg, 1991].

Possibly the most useful measure for determining the extent of the gender pay gap in its broadest sense, across the entire workforce, is the mean figure for all employees, which includes both full-time and part time workers. On this measure the gender pay gap is much higher, standing at 19.3 per cent in April 2010, down from 20.1 per cent a year earlier. This measure captures a number of the elements feeding into the real differences in take-home pay between men and women, such as the fact that many more women than men work part-time. The main reason why the figure is so high, higher even than the figures for parttime or full-time employees separately is that the proportion of women working part-time is much higher than the proportion of men doing so. Since part-time work is lower-paid than fulltime work, this drags down the mean hourly wage for women to $f 12.92$, compared to a mean figure for all male workers of $\mathrm{f} 16.00$ an hour. The difference between these two figures is the basis for the gap.

\title{
4. Why Does the Gap Persist?
}

Two main factors contribute to the gender pay gap. The first is the difference between the earnings of men and women in the same jobs, as indicated by the table hereunder. Of the 289 occupations for which it is possible to calculate the gender pay gap using ASHE data, 251 shows a pay gap in favour of men. The remaining 38 occupations show a pay gap in favour of women, though in all but 12 of these either the number of men or the number of women employed in the role in the ASHE sample is so small that it is 


\author{
(online) $=$ ISSN $2285-3642$ \\ ISSN-L = 2285 - 3642 \\ Journal of Economic Development, Environment and People \\ Volume 5, Issue 2, 2016 \\ URL: http://jedep.spiruharet.ro \\ e-mail: office jedep@spiruharet.ro
}

statistically insignificant. Many of the jobs in which the gender pay gap is in favour of women are relatively low-paid, such as security guards and kitchen assistants.

Table 1. Gender Pay Gap in selected occupations in 2010

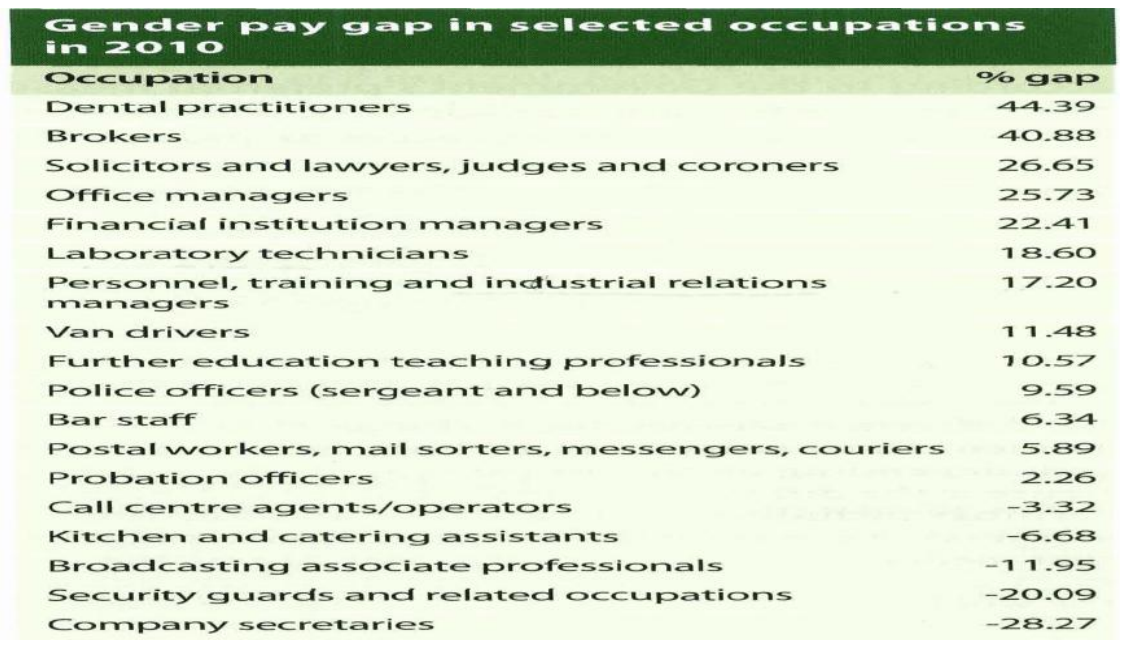

Source: Annual Survey of Hours and Earnings (ASHE), April 2010

Long pay scales and pay systems using broad bands are thought to exacerbate this problem. Women are still much more likely to take lengthy career breaks than men, meaning that men continue to progress through the grade while women's progression is stalled [Zacharakis, et al, 2001].

Employers can avoid contributing to a worsening of the gender pay gap by shortening lengthy pay scales, reducing the number of years typically taken to get to the top of the grade. This allows women's earnings to catch up with those of their male colleagues even following a career break of one or more years.

\title{
5. Occupational Segregation
}

The second main factor contributing to the gender pay gap is occupational segregation, whereby women tend to dominated the lowest-paid jobs while the highest-paying roles tend to be male-dominated. The table 2 shows that in the 10 highest-paying occupations, women are significantly underrepresented in the ASHE sample, with the number of women employed in five of these roles so small as to not be considered statistically significant. Looking at the ten lowest-paid occupations on the other hand, women are over-represented in the sample, making up well over half of the workforce in eight of the ten roles. 


\author{
(online) $=$ ISSN $2285-3642$ \\ ISSN-L = $2285-3642$ \\ Journal of Economic Development, Environment and People \\ Volume 5, Issue 2, 2016 \\ URL: $\underline{\text { http://jedep.spiruharet.ro }}$ \\ e-mail: office jedep@spiruharet.ro
}

Table 2. Highest and lowest-earning occupations

\begin{tabular}{llll}
\hline Highest and lowest-earning occupations & & Average full-time gross pay \\
fpw & $\begin{array}{l}\text { \% of women (full and part- } \\
\text { time) in ASHE sample }\end{array}$ & 50 \\
\hline Dental practitioners & 1,095 & $*$ \\
Police officers (inspectors and above) & 1,161 & $*$ \\
Managers in mining and energy & 1,176 & 36 \\
Air traffic controllers & 1,189 & 23 \\
Financial managers and chartered secretaries & 1,296 & $*$ \\
Brokers & 1,345 & $*$ \\
Senior officials in national government & 1,357 & 42 \\
Aircraft pilots and flight engineers & 1,408 & 17 \\
Medical practitioners & 1,459 & \\
Directors and chief executives of major organisations & 2,049 & 61 \\
10 lowest-paying occupations & & 43 \\
Bar staff & 258 & 75 \\
Leisure and theme park attendants & 268 & 68 \\
Retail cashiers and check-out operators & 268 & 67 \\
Waiters, waitresses & 268 & $* *$ \\
Kitchen and catering assistants & 269 & 74 \\
Floral arrangers, florists & 269 & 50 \\
Launderers, dry cleaners, pressers & 272 & 87 \\
Elementary personal services occupations & 275 & $*$ \\
Hairdressers, barbers & 293 & \\
Hotel porters & 293 & \\
*Proportion of women in sample is statistically insignificant. & & \\
*:Proportion of men in sample is statistically insignificant. & & \\
\hline & & \\
\hline
\end{tabular}

Source: Annual Survey of Hours and Earnings (ASHE), April 2010

\title{
6. Earnings Distribution
}

The two graphs opposite show the distribution of gross weekly earnings for men and women, indicating the number of workers whose weekly earnings fall within each $f 10$ interval. Female earnings reach their peak much lower down the distribution than male earnings, with the highest point on the graph of female earnings at around $£ 330$ a week. The peak in the male earnings distribution is less pronounced, but is around the $£ 390$ a week mark.

Further up the earnings distribution, the number of women in each $f 10$ interval rapidly declines, while a longer 'tail' of typical high-paid jobs is visible on the male earnings distribution. Just $2.9 \%$ of women earn over $f 1000$ a week, compared to $12.1 \%$ of men. Above this level, the number of women earning over $f 2,000$ a week in the ASHE sample is so small that it does not show up in the figures, while 1.6 per cent of males earn over this amount. 


\author{
(online) = ISSN $2285-3642$ \\ ISSN-L = 2285 - 3642 \\ Journal of Economic Development, Environment and People \\ Volume 5, Issue 2, 2016 \\ URL: http://jedep.spiruharet.ro \\ e-mail: office jedep@spiruharet.ro
}

Charter 2. Distribution of gross weekly earning for full-times female employees, April 2010

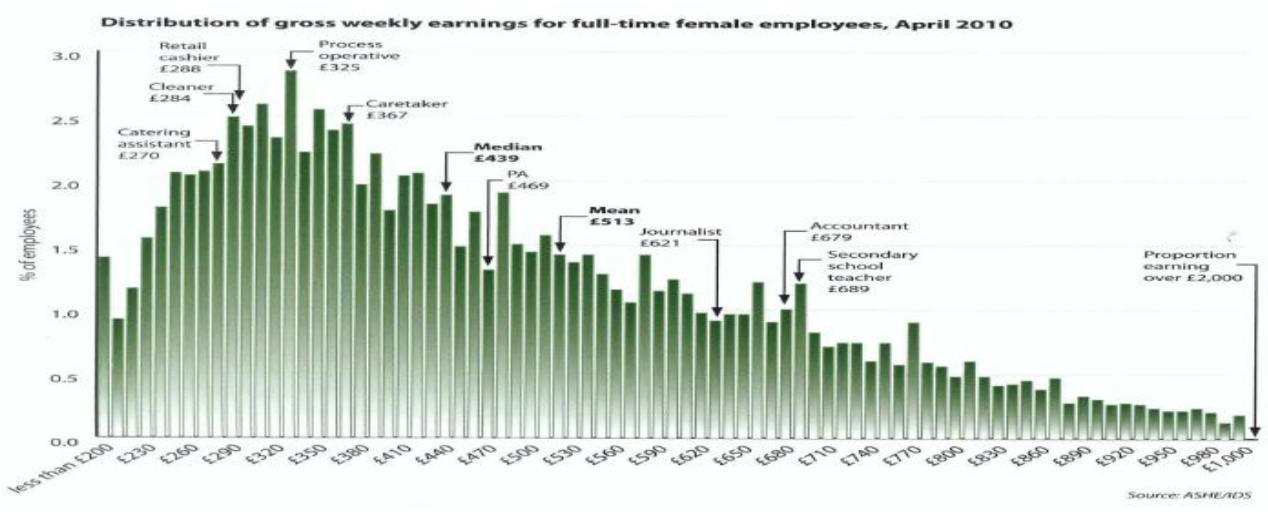

Source: Annual Survey of Hours and Earnings (ASHE), April 2010

Charter 3 Distribution of gross weekly earning for full time male employees, April 2010

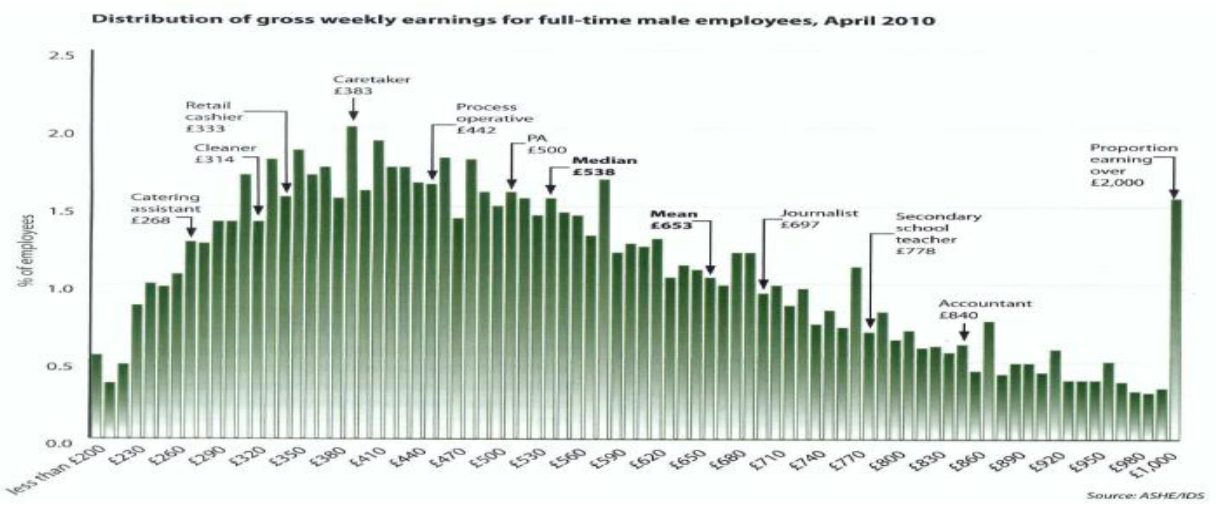

Source: Annual Survey of Hours and Earnings (ASHE), April 2010

\title{
7. Case Study for a UK Logistics Company
}

Taking into consideration the advantages and disadvantages of using either median or mean way of calculation for this case study, we decided to use both methods. Where averages are to be used for comparative purposes it is not desirable for the results to be affected by unusually high or low results. 


\author{
(online) $=$ ISSN $2285-3642$ \\ ISSN-L = 2285 - 3642 \\ Journal of Economic Development, Environment and People \\ Volume 5, Issue 2, 2016 \\ URL: http://jedep.spiruharet.ro \\ e-mail: office jedep@spiruharet.ro
}

The median is therefore the most appropriate measure in cases such as these, since it is simply the middle value, and takes little account of the extent of differences between figures in the sample. However, when calculating the gender pay gap, it is precisely these variations that we intend to measure.

For in depth analysis we studied the independent variables using a regression. Data based used: Oracle UK salary database.

Our findings:

MEAN (AVERAGE) - salary/hour

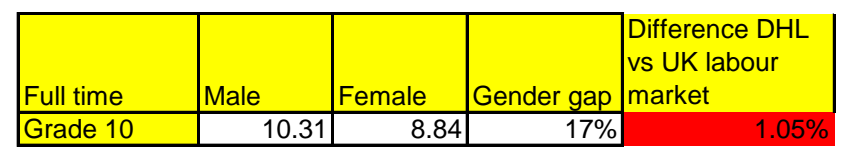

\begin{tabular}{|l|r|r|r|}
\hline Full time & Male & Female & Gender gap \\
\hline Grade 9 & 12.17 & 10.70 & $14 \%$ \\
\hline
\end{tabular}

\begin{tabular}{|l|r|r|r|}
\hline Full time & Male & Female & Gender gap \\
\hline Grade 8 & 14.39 & 13.46 & $7 \%$ \\
\hline
\end{tabular}

\begin{tabular}{|l|r|r|r|}
\hline Full time & Male & Female & Gender gap \\
\hline Grade 7 & 18.60 & 18.07 & $3 \%$ \\
\hline
\end{tabular}

\begin{tabular}{|l|r|r|r|}
\hline Grade 7 & 18.60 & 18.07 & $3 \%$ \\
\hline
\end{tabular}

\begin{tabular}{|l|r|r|r|}
\hline Full time & \multicolumn{1}{|l|}{ Male } & Female & Gender gap \\
\hline Grade 6 & 25.19 & 23.80 & $6 \%$ \\
\hline
\end{tabular}

\begin{tabular}{|l|r|r|r|}
\hline Full time & Male & Female & Gender gap \\
\hline Grade 5 & 35.38 & 31.87 & $11 \%$ \\
\hline
\end{tabular}

\begin{tabular}{|l|r|r|r|}
\hline Full time & Male & Female & Gender gap \\
\hline overall DHL & 12.40 & 11.67 & $6 \%$ \\
\hline
\end{tabular}

In column "Differences DHL vs. UK labour market" we noted in red all the percentages that are above the percentage of the UK labour market gender gap.

Regression for this population:

\begin{tabular}{crrrrr}
\hline & Coefficients & Standard Error & \multicolumn{1}{c}{$t$ Stat } & \multicolumn{1}{c}{$P$-value } \\
\hline Intercept & 70392.39451 & 13940.36271 & 5.049538 & $4.5 \mathrm{E}-07$ \\
\cline { 1 - 1 } Gendre & 709.9276191 & 50.83816483 & 13.96446 & $6.42 \mathrm{E}-44$ \\
Age & 10.71125543 & 1.755846628 & 6.100337 & $1.1 \mathrm{E}-09$ \\
Date start & -29.16561688 & 6.929857247 & -4.208689 & $2.59 \mathrm{E}-05$ \\
Normal Hours & & 0.935439704 & 0.141673612 & 6.60278 & $4.23 \mathrm{E}-11$ \\
Working Days & & 460.6001668 & 30.69485252 & 15.00578 & $2.28 \mathrm{E}-50$ \\
\cline { 1 - 1 } Employee category & & 9.822132137 & 1.088979307 & 9.019576 & $2.22 \mathrm{E}-19$ \\
\hline
\end{tabular}




\author{
(online) $=$ ISSN $2285-3642$ \\ ISSN-L = 2285 - 3642 \\ Journal of Economic Development, Environment and People \\ Volume 5, Issue 2, 2016 \\ URL: $\underline{\text { http://jedep.spiruharet.ro }}$ \\ e-mail: office jedep@spiruharet.ro
}

Independent variables that have an impact on salary are: age, starting date of the current job position and normal hours (working hours).

\title{
8. Outcome and Conclusions:
}

For this particular logistic company there are differences [Angheluta, Costea, 2011] between the earnings of men and women on the same jobs due to following factors:

- There is an age gap: $36 \%$ of the male population are age between $17-33$ years old, while $51 \%$ of females are in that range (less working experience);

- $53 \%$ of the male population are on the current job before 2007 , compared with $41 \%$ females that are in the same range (more working experience);

- $41 \%$ of the total male population are working between $40-50 \mathrm{~h} /$ week compared with $31 \%$ of the female population;

- Other reasons: DHL industry or customer performance [Angheluta, Costea, 2010] (17\% more females are working in Department store and Fashion).

In order to understand better the root cause of the gender payment discrepancies we focused on grade 10 population, function operations, date of starting position 2008, employee category 20 (warehouse operatives) [Costea, Angheluta, 2010]:

- For age 26, 28 and 30, salaries were the same for males and females;

- In some cases, males were paid less than females, but not the other way around

- The salaries' gap was due to affiliation of the organization.

However we compare salaries of females vs. those of males and take into consideration the same independent variables with the same range values and we cannot see gender payment gaps. This is very difficult to put into practice [Budlender, Hewitt, 2003] for all roles since when a role becomes more complex the independent variables increase in number and complexity so the comparison it's almost impossible to be done.

\section{UK Benchmarking Tool 2011}

In order to eliminate or at least reduce gender pay gaps we developed a tool that can be used to benchmark the similar positions in the UK labour market: 


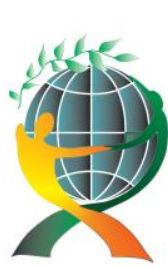

$$
\begin{gathered}
\text { (online) }=\text { ISSN } 2285-3642 \\
\text { ISSN-L = 2285 - } 3642
\end{gathered}
$$

Journal of Economic Development, Environment and People

Volume 5, Issue 2, 2016

URL: http://jedep.spiruharet.ro

e-mail: office jedep@spiruharet.ro

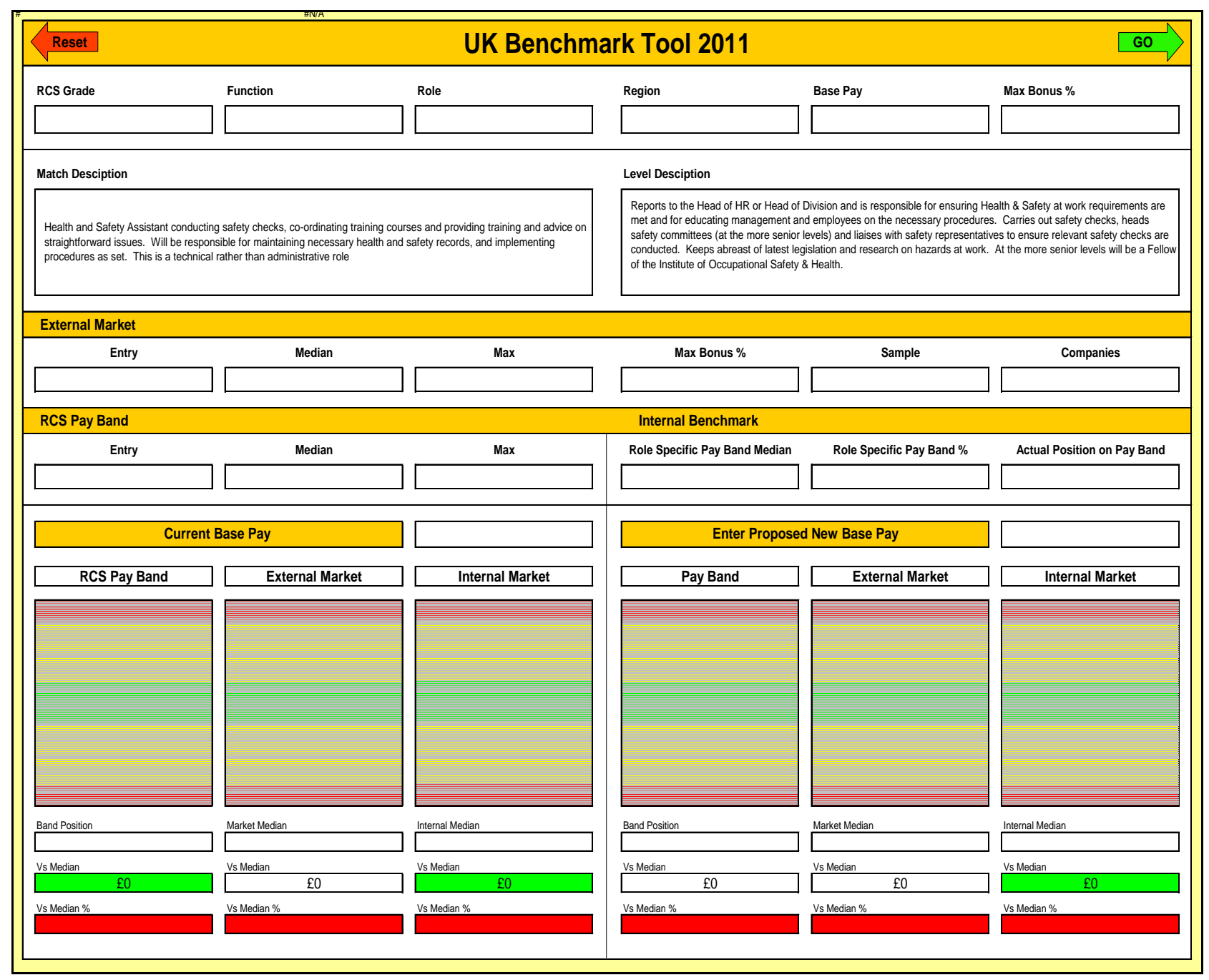

It contains some mandatory fields that should be filled in like: RCS grade, function, role, region, base pay, maximum bonus. This tool enables the users to evaluate the company's salary against the UK labour market. Nevertheless this model can be used worldwide because it has a database that can be updated at any country level.

This state of the art tool will give companies competitive advantages since nowadays human resources are the most valuable and important resources for firms. This is the reason why you need to have motivated employees in order to increase retention rate and human productivity. 


\author{
(online) $=$ ISSN $2285-3642$ \\ ISSN-L = $2285-3642$ \\ Journal of Economic Development, Environment and People \\ Volume 5, Issue 2, 2016 \\ URL: http://jedep.spiruharet.ro \\ e-mail: office jedep@spiruharet.ro
}

\title{
10. References
}

[1] Annual Survey of Hours and Earnings (ASHE), April 2010

[2] Andrei Angheluta, Project on Cross gender DHL salary comparison, DHL, 2011

[3] A., Angheluta, C.Costea, (2011), Sustainable go-green logistics solutions for Istanbul metropolis. Transport Problems Journal 6 (2): 59-70. http://transportproblems.polsl.pl/pl/Archiwum/2011/zeszyt2/2011t6z2 08.pdf.

[4] Angheluta, A., Costea C., (2010) Utilization of e-Logistics in multinational companies to overcome difficulties of today's economic environment, Management Marketing, ISSN $1842-0206$ Vol 5 no. 1 http://www.managementmarketing.ro/arhiva.php?var[22]=en\&var[1]=1\&var[3]=2010

http://ideas.repec.org/a/eph/journl/v5y2010i1n6.html;

http://www.managementmarketing.ro/autori.php?var[22]=ro\&var[0]=autori\&var[1]=Carmen\%20COSTEA\&var[2] $\underline{=177}$

[5] Blumberg, Rae, (1991), "Income under Female versus Male Control." In Blumberg, Rae, eds., Gender, Family and Economy: The Triple Overlap. Newbury Park, CA: Sage Press.

[6] Budlender, Debbie, and Guy Hewitt, (2003), Gender Budgets Make More Cents. Country Studies and Good Practices. London: Commonwealth Secretariat.

[7] Costea, C., and A. Angheluta, Contributions to the development of e-logistics as a smart process, in International Journal - Dynamics of Socio-Economic Systems JDYSES 2 (1): $63-80$. http://www.dyses.org.ar/ojs2333/index.php/idyses/article/view/16.

[8] Delistavrou A., Tilikidou, I. (2014), Are Greeks' Unconcerned about Ethical Market Choices?, Journal of Economic Development, Environment and People Vol. 3, Issue 4 URL: http://jedep.spiruharet.ro acc at 13.03.2016

[9] IDS Pay Report, Research and analysis on pay and benefits, No. 1065, January 2011

[10] Knowles, Stephen, et al, "Are Educational Gender Gaps a Brake on Economic Development? Some Cross-Country Empirical Evidence." Oxford Economic Papers 54: 118-149, 2002

[11] DFID (Department for International Development). (20000, Breaking the Barriers: Women and the Elimination of World Poverty. UK: DFI

[12] Zacharakis, A. L. et al, (2001) Global Entrepreneurship Monitor National Entrepreneurship Assessment: United States of America 2001 Executive Report. Ewing Marion Kauffman Foundation: Kauffman Center for Entrepreneurial Leadership. 